\title{
The diversity and abundance of Hymenoptera insects on tidal swamp rice field in Indragiri Hilir District, Indonesia
}

\author{
ZAHLUL IKHSAN $^{1, \boldsymbol{}}$, HIDRAYANI $^{2}$, YAHERWANDI ${ }^{2}$, HASMIANDY HAMID ${ }^{2}$ \\ ${ }^{1}$ Postgraduate Program, Faculty of Agriculture, Universitas Andalas. Jl. Unand, Limau Manih, Padang 25163, West Sumatra, Indonesia \\ Tel./fax.: +62-751-71181, `email: zahlul_ikh@yahoo.com \\ ${ }^{2}$ Faculty of Agriculture, Universitas Andalas. Jl. Unand, Limau Manih, Padang 25163, West Sumatra, Indonesia
}

Manuscript received: 25 September 2019. Revision accepted: 12 February 2020.

\begin{abstract}
Ikhsan Z, Hidrayani, Yaherwandi, Hamid H. 2020. The diversity and abundance of Hymenoptera insects on tidal swamp rice field in Indragiri Hilir District, Indonesia. Biodiversitas 21: 1020-1026. Hymenoptera is one of the four largest insect orders and it plays a vital role in human life as pollinators, parasitoids, and predators. Hymenoptera parasitoids are particularly important as agents of biological control of pest. The objective of this research was to study the diversity and abundance of Hymenoptera on tidal swamp rice field in Indragiri Hilir District, Riau Province, Indonesia. Samplings were conducted in 3 sub-districts of rice production centers, namely Batang Tuaka, Keritang and Reteh, using four trapping techniques (i.e. insect net, malaise trap, pitfall trap, and yellow pan trap). Shannon diversity index (H '), Krebs evenness index (E), and Jaccard similarity index (Is) were calculated. We found 4,701 individuals consisting of 39 families and 319 species of Hymenoptera at the three studied areas. Tidal swamp rice in Indragiri Hilir District had a high species diversity of Hymenoptera parasitoids and Hymenoptera predators, but a moderate species diversity of Hymenoptera pollinators. Species diversity and evenness of Hymenoptera parasitoids and predators were higher in Keritang than in Batang Tuaka and Reteh. The families of Formicidae, Braconidae, Ichneumonidae, and Scelionidae had the highest number of species, while Formicidae, Scelionidae, Diapriidae, and Braconidae had the highest number of individuals. Based on these findings, the abundance and diversity of Hymenoptera insects in Indragiri Hilir District have the potentials to be developed as biological agents to control pests on tidal swamp rice in this area.
\end{abstract}

Keywords: Diversity, Hymenoptera, parasitoid, tidal swamp rice

\section{INTRODUCTION}

Rice (Oryza sativa L.) is the main food commodity in Indonesia because it is the staple food for most Indonesians. National rice demands increase along with the increase of human population. Therefore, rice has been one of the major commodities for self-sufficiency in the government's development targets. It was targeted to be reached in 2017, which then included in special programs in 2017 and 2018. One of the strategies to increase national rice production is by expanding the extent of rice cultivation areas in which one of the plans is maximizing the use of peatlands for tidal swamp rice.

Increasing cropland areas can lead to increasing the availability of food for pests, resulting in an increase in pest populations. This adverse situation should be anticipated in advance. However, farmers in Indonesia have been very used to using chemical pesticides excessively to control pest populations without regard to natural pest enemies existing in the fields. It is dilemma for the farmers to not rely on insecticides even though their negative impacts are known, for example, the pesticides will also unintentionally eradicating pest's natural enemies (Hidrayani et al. 2013).

Conserving and increasing the function of pest's natural enemies is one of the main components in Integrated Pest Management (IPM) to suppress pest attacks to remain below the economic profitability threshold of agricultural production. Utilizing pest's natural enemies (e.g. predators, parasitoids, and insect pathogens) are environmentally friendly and do not cause pest resistance and resurgence. Organic rice cultivation system with no or limited use of chemical materials increased the biodiversity of useful insects (e.g. predators, parasitoids, pollinators, and decomposers) in two planting seasons (Ovawanda et al. 2016). A taxa group that is potentials as useful insects are Hymenoptera.

Hymenoptera is widely distributed across various agricultural lands, forests, or other places that have food sources for these insects, such as flowering plant vegetation and vegetable gardens. Hymenoptera is composed of 2 suborders, 27 superfamilies, 132 families, 8423 extant genera with an additional 685 extinct genera. Considered as one of the most species-rich insect orders, a total of 153088 extant species have been described, in addition to 2429 extinct species (Aguiar et al. 2013). The group of Hymenoptera Parasitika was found to be more abundant $(96 \%)$ and more diverse $(84 \%)$ than the Aculeata group. Habitat conditions around paddy fields (blocks) and age of rice plants affect Hymenoptera Parasitika (Herlina et al. 2011). Fourteen species of parasitoids were included in the family of Chalcidoidea, Bethylidae, Braconidae, Ichneumonidae, Eulopidae, Vespidae, Diapriidaae, Pteromalidae, Platygastroidea, Pipunculidae, Lygaeidae (Rosa and Mariana 2012).

Indragiri Hilir District in Riau Province, Indonesia is mostly dominated by peatland areas. Now, this district is 
being developed for rice planting extensification and one of the aspects to study is the state of useful insects, mainly from Hymenoptera. Previous study showed that Hymenoptera was the highest insect population at the time before rice planting in Indragiri Hilir District (Ikhsan et al. 2018). However, it is not clear whether the existence of Hymenoptera is potentials to be used to control pest populations. This research aimed to study the diversity of Hymenoptera parasitoids at three stages of rice cultivation on tidal swamp rice field in Indragiri Hilir District, Riau Province, Indonesia.

\section{MATERIALS AND METHODS}

\section{Study area and period}

The study was conducted in three sub-districts of rice production centers in Indragiri Hilir District from February until October 2018. The three sub-districts are Batang Tuaka $\left(0^{\circ} 20^{\prime} 19^{\prime \prime} \mathrm{S}, 103^{\circ} 2^{\prime} 53^{\prime \prime}\right.$ E), Reteh $\left(0^{\circ} 40^{\prime} 04^{\prime \prime} \mathrm{S}\right.$, $\left.103^{\circ} 08^{\prime} 06^{\prime \prime} \mathrm{E}\right)$, Keritang ( $0^{\circ} 42^{\prime} 29^{\prime \prime} \mathrm{S}, 103^{\circ} 0^{\prime} 28^{\prime \prime} \mathrm{E}$ ) (Figure 1). Insect identification was carried out at the Insect Bioecology Laboratory, Faculty of Agriculture, University of Andalas, Padang, West Sumatra Province.

\section{Insect collection}

Insect samples were collected using the malaise trap, pitfall trap, sweep net, and yellow pan trap (Darnaedi and Noerdjito 2007). The collections were done at three different stages of rice cultivation: before planting, vegetative stage, and generative stage. The condition before planting referred to as the stage before the land was cultivated, and there was still vegetation. In the vegetative stage, the insects were collected when the rice plants were about one month old. In the generative stage, the insects were collected when the rice plants were about two months old. In every sub-district, one area of peatland rice with minimum size of $1000 \times 500 \mathrm{~m}^{2}$ was assigned as a sampling location. Two transect lines (1000 m length each) were made in every area with minimum distance between transect line $300 \mathrm{~m}$. In each line, there were ten sampling plots $\left(1 \mathrm{x} 1 \mathrm{~m}^{2}\right)$ with a distance between sample plots $100 \mathrm{~m}$. So, in each transect line, there were ten sampling plots. In each plot, the sample plant was determined systematically by making a diagonal line of sub-samples of $1 \times 1 \mathrm{~m}^{2}$. In each sample sub-plot, insect collections were carried out.

(i) Malaise trap: Malaise trap was installed at each research location, each with one malaise trap. The installation of the malaise trap was based on the direction of the wind, which was facing north or south. Generally, insects that are actively flying and foraging prefer light like sunlight, if these insects fly and pass through these traps, the insect is more easily trapped when compared to mounting according to the sun's rise because this trap is designed for insects from the side, not from the front. Trapped insects were collected in a bottle that was filled with $96 \%$ alcohol. This trap was installed for one week in each phase of rice cultivation. Then the trapped sample was transferred to the sample bottle and labeled.
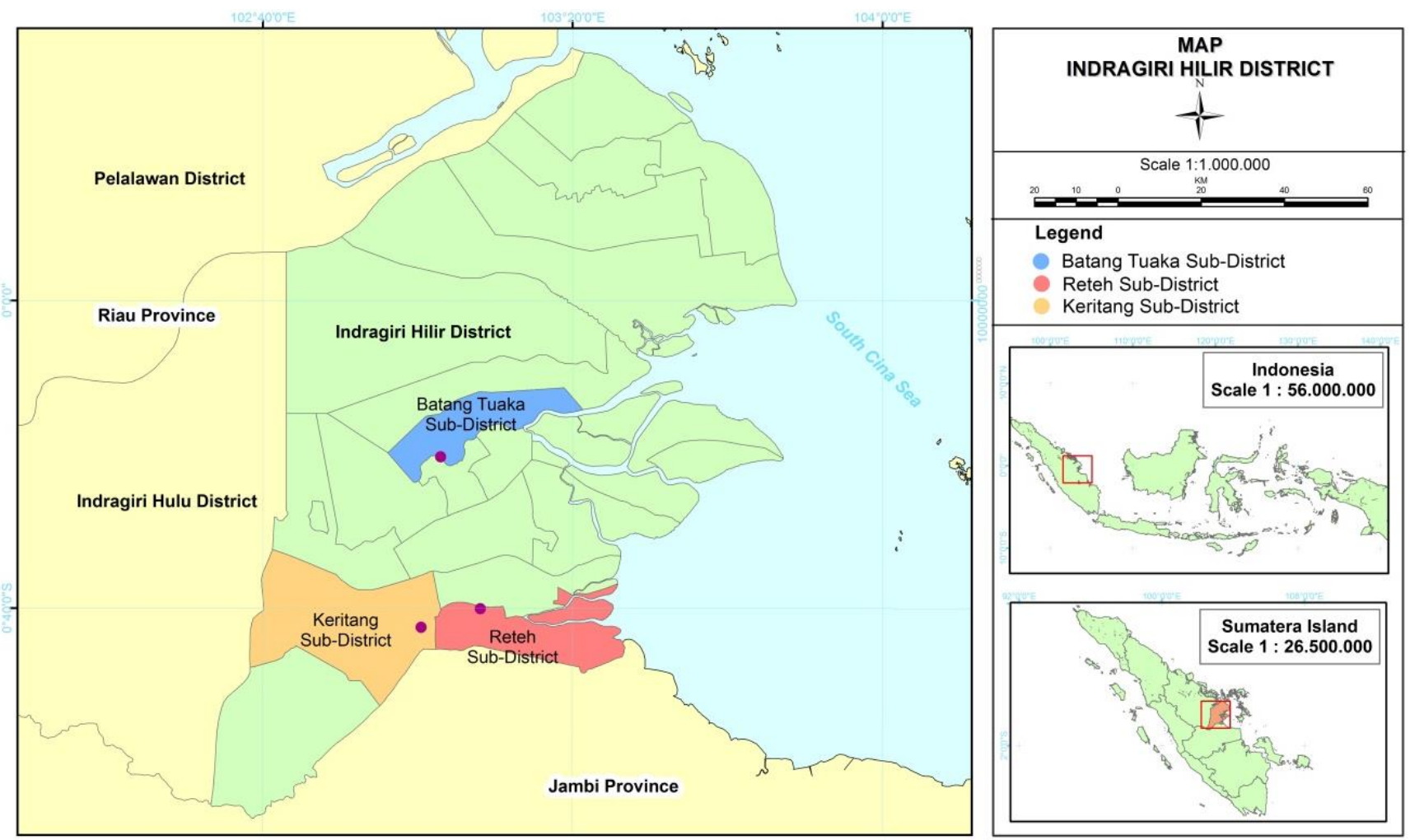

Figure 1. Map of study area in Indragiri Hilir District, South Sumatra, Indonesia 
(ii) Pitfall trap: Pitfall trap was made of plastic glass with diameter of $\pm 7 \mathrm{~cm}$ and height of $\pm 10 \mathrm{~cm}$. The glass was filled with $\pm 50 \mathrm{ml}$ of detergent solution to reduce surface tension, so that trapped insects will sink and die. Pitfall traps are used to trap Hymenoptera, which are active at the ground surface. The trap was installed by implanting it into the ground, and the top was parallel to the ground surface. Two traps were installed in each sample plot for 24 hours. Installation was carried out diagonally in $1 \times 1 \mathrm{~m}^{2}$ sample plot.

(iii) Sweep net: Sweep net was set up on each sample. We did ten double swings. Insects that were caught immediately put into a film bottle containing $96 \%$ alcohol. In the laboratory, pest's natural enemies (i.e. parasitoids and predators) were separated from other insects, and each morphospecies were separated, then inserted into $2 \mathrm{ml}$ Eppendorf, which contained $96 \%$ alcohol for identification purpose.

(iv) Yellow pan trap: Yellow pan trap was used to catch insects interested in yellow. Collecting insects with a yellow pan trap was done by placing one yellow pan trap on each sample bed. The yellow pan trap was filled with detergent water to reduce the surface pressure of the water so that the insects that enter will sink and die. Installation of a yellow trap was done in the morning before 09.00 A.M., then taken back in the afternoon. The trapped insects were filtered and taken using a brush so as not to damage parts of the insect. Then the insects were inserted into a film bottle that has been filled with $96 \%$ alcohol to be identified in the laboratory.

\section{Identification of insect}

Identification was carried out at the Insect Bioecology Laboratory of Andalas University, Padang, Indonesia using a binocular microscope. Identification was carried out on imago. All insects obtained were separated by order. Insect identification was based on the main morphological characteristics of the mouth, antennae, wings, legs, and skin color. The insects obtained were photographed so that they can produce images for documentation. Hymenoptera insects were identified further up to the level of the family and morphospecies (coded). Hymenoptera identification was conducted to family level and functional grouping. The identification used various references, namely Kalshoven (1981), Goulet and Huber (1993), Triplehorn and Johnson (2004), official websites http://www.bugguide.net; http://www.antwiki.org and related articles.

\section{Data analysis}

Several parameters were calculated in data analysis. Diversity index was calculated index using the Shannon-
Wiener formula. Species Evenness Index was calculated using the Simpson Evenness Index, which measured the proportion of each species in a population at a certain place and time according to formula by Krebs (2000). Species Similarity Index was calculated to determine the proportion of species similarity between two communities using the Jaccard species similarity index.

\section{RESULTS AND DISCUSSION}

Sebatu Village of Batang Tuaka Sub-district, Pebenaan Village of Keritang Sub-district, and Mekarsari Village of Reteh Sub-district were the area that conducted rice planting activities in each planting season. Sebatu and Mekarsari villages planted local varieties of rice with monoculture system, while Pebenaan Village planted IR42 variety with polyculture system. Farmers in the research location did not use chemical fertilizers and pesticides in rice cultivation. They only used herbicides to overcome weeds at the time before planting. The extent of land being observed in each location was \pm 100 ha. The description of the research location can be seen in Table 1 .

We found 4,701 Hymenoptera individuals consisting of 39 families and 319 morphospecies trapped at three studied areas on tidal swamp rice in Indragiri Hilir District, Riau Province. Families of Formicidae, Braconidae Ichneumonidae and Scelonidae had the highest number of species (Figure 2), while Formicidae, Scelionidae, Diapriidae, and Braconidae had the highest number of individuals (Figure 3 ).

In this study, Ichneumonidae and Braconidae were parasitoid Hymenoptera family with the highest number of morphospecies (Figure 2). Both families come from the Ichneumonidea superfamily. The two families have the highest number of species compared to others and almost dominate the entire ecosystem (Thamrin 2011). In agriculture ecosystem planted with vegetables, monoculture and polyculture, Ichneumonidae and Braconidae are families that have the highest relative abundance (> 15\%) (Hariyanti 2015). Another study also found that Braconidae and Ichneumonidae were the dominant parasitoid Hymenoptera families in vegetable agriculture ecosystems in West Sumatra (Yaherwandi 2012). In addition, Ichneumonidae and Braconidae families also dominated forest areas, including in Mount Halimun National Park (TNGH) (Siregar et al. 2016).

Table 1. Study location description in Indragiri Hilir District, South Sumatra, Indonesia

\begin{tabular}{|c|c|c|c|}
\hline Name of location & $\begin{array}{l}\text { Agriculture } \\
\text { system }\end{array}$ & $\begin{array}{l}\text { Coordinates and } \\
\text { altitude }\end{array}$ & Vegetation \\
\hline $\begin{array}{l}\text { Sebatu Village, } \\
\text { Batang Tuaka Sub-district }\end{array}$ & Monoculture & $\begin{array}{l}0^{\circ} 20^{\prime} 19^{\prime \prime} \mathrm{S}, 103^{\circ} 2^{\prime} 53^{\prime \prime} \mathrm{E} \\
1-6 \mathrm{~m} \text { asl }\end{array}$ & Oryza sativa, Elaeis guineensis, Areca catechu \\
\hline $\begin{array}{l}\text { Mekarsari Village, } \\
\text { Reteh Sub-district }\end{array}$ & Monoculture & $\begin{array}{l}0^{\circ} 400^{\prime} 04^{\prime \prime} \mathrm{S}, 103^{\circ} 08^{\prime} 06^{\prime \prime} \mathrm{E} \\
1-6 \mathrm{~m} \text { asl }\end{array}$ & $\begin{array}{l}\text { Oryza sativa, Elaeis guineensis, Areca catechu, Nypa } \\
\text { fruticans }\end{array}$ \\
\hline $\begin{array}{l}\text { Pembenaan Village, } \\
\text { Keritang Sub-district }\end{array}$ & Polyculture & $\begin{array}{l}0^{\circ} 42^{\prime} 29^{\prime \prime} \mathrm{S}, 103^{\circ} 0{ }^{\prime} 28^{\prime \prime} \mathrm{E} \\
2-6 \mathrm{~m} \text { asl }\end{array}$ & $\begin{array}{l}\text { Oryza sativa, Capsicum annum, beans, Musa paradisiaca, } \\
\text { Areca catechu, Nypa fruticans, Cocos nucifera }\end{array}$ \\
\hline
\end{tabular}




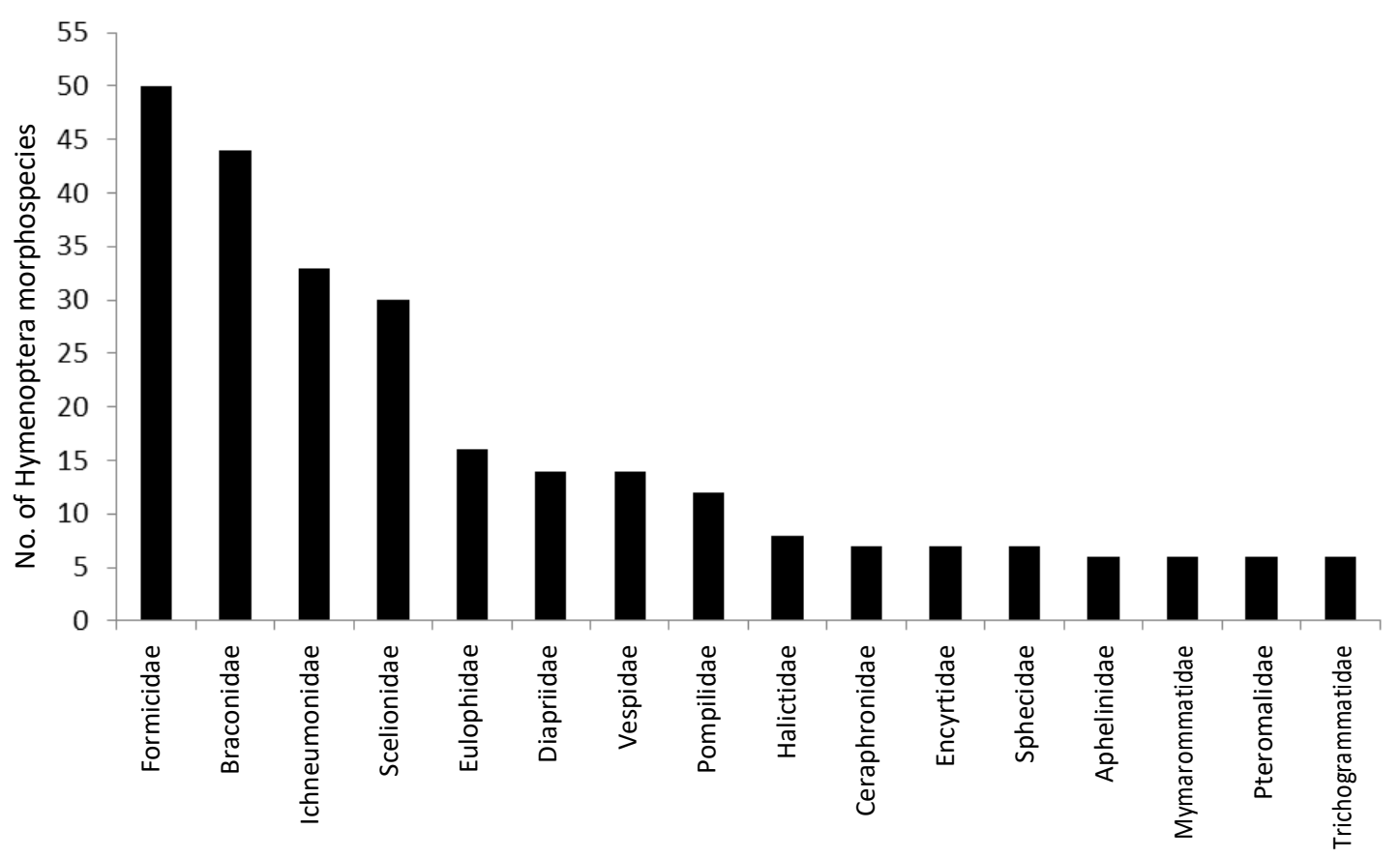

Figure 2. Total of morphospecies of each Hymenoptera family at three study areas in Indragiri Hilir District, South Sumatra, Indonesia

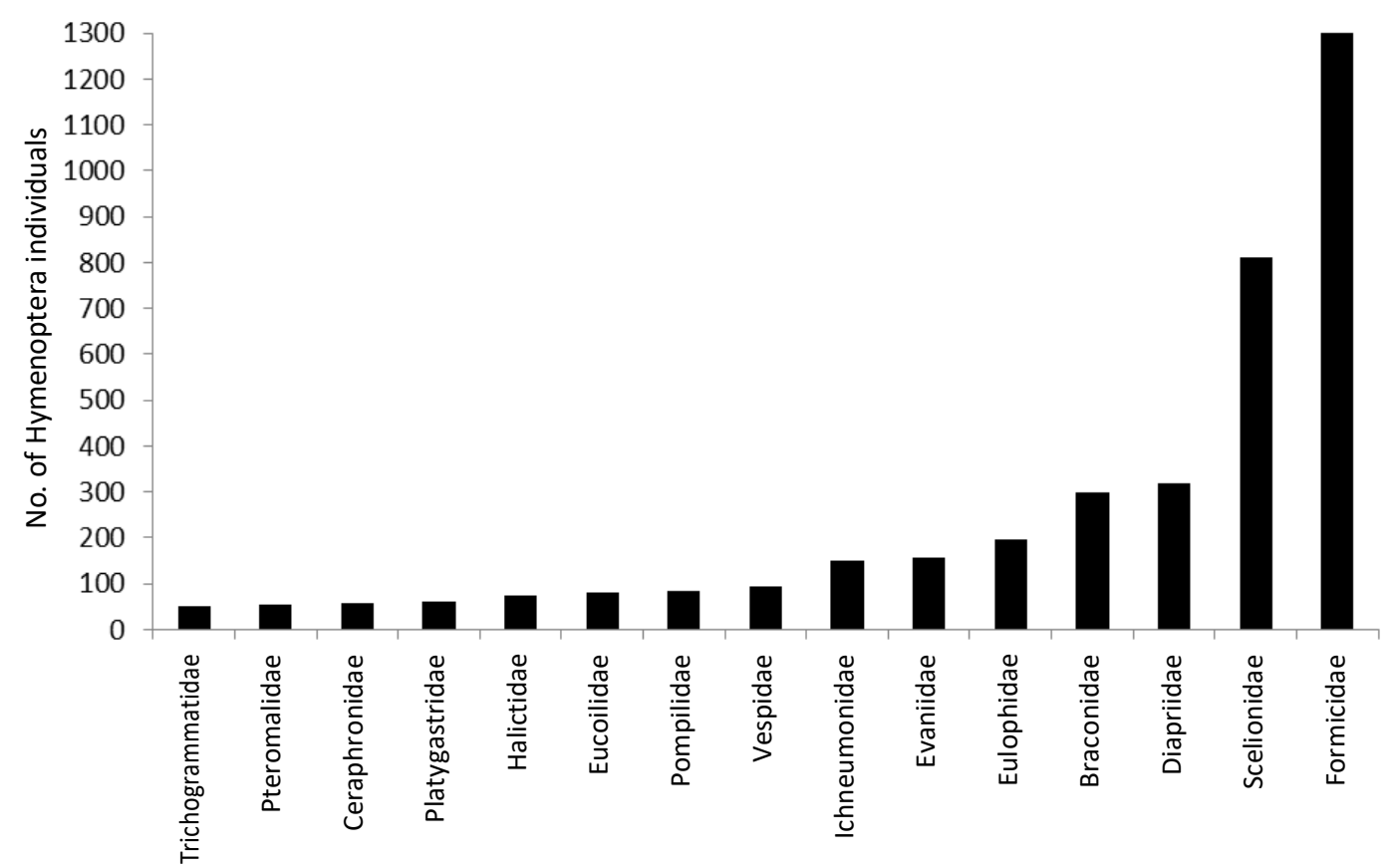

Figure 3. Total of individual of each Hymenoptera family at three study sites in Indragiri Hilir District, South Sumatra, Indonesia

We found that Scelionidae and Braconidae were parasitoid Hymenoptera families with the highest number of individuals. This is because there were abundant food sources from various plants in the agricultural ecosystem which support their living system. Landscape structure, flowering plants, and pesticide application affected species richness, diversity, and evenness of Hymenoptera parasitoid in non-crop vegetation (Yaherwandi et al. 2008). If the hosts are abundant, the parasitoids are also abundant. Conversely, if food sources, shelter, breeding grounds, and other environmental factors are insufficient, the abundance of parasitoid Hymenoptera will decrease (Untung 1996).

The more detailed results of our sampling at the three studied areas in Indragiri Hilir District is presented in Table 2. Keritang Sub-district has the highest number of morphospecies and the number of individuals compared to Batang Tuaka and Reteh. This is likely due to Keritang 
Sub-district implemented a polyculture planting system while the other two applied monoculture farming. Our finding strengthens the statement by Herlinda (2007) that the more diverse vegetation, the fauna diversity is higher. Another study by Yaherwandi et al. (2008) reported that
Nyalindung which had a more complex structure and consisting of rice, pulses, and vegetable ecosystems had a higher number of individuals, species, and Hymenoptera families to Gasol and Selajambe, which consisted monoculture rice farming.

Table 2. The detailed results of insect sampling at three studied areas in Indragiri Hilir District, South Sumatra, Indonesia

\begin{tabular}{|c|c|c|c|c|c|c|c|c|}
\hline \multirow[b]{2}{*}{ Superfamily } & \multirow[b]{2}{*}{ Family } & \multicolumn{2}{|c|}{ Batang Tuaka } & \multicolumn{2}{|c|}{ Keritang } & \multicolumn{2}{|c|}{ Reteh } & \multirow[b]{2}{*}{$\begin{array}{c}\text { Role in } \\
\text { ecosystems }\end{array}$} \\
\hline & & $\begin{array}{c}\text { No. of } \\
\text { morphospecies }\end{array}$ & $\begin{array}{c}\text { No. of } \\
\text { individual }\end{array}$ & $\begin{array}{c}\text { No. of } \\
\text { morphospecies }\end{array}$ & $\begin{array}{c}\text { No. of } \\
\text { individual }\end{array}$ & $\begin{array}{c}\text { No. of } \\
\text { morphospecies }\end{array}$ & $\begin{array}{c}\text { No. of } \\
\text { individual }\end{array}$ & \\
\hline \multirow[t]{4}{*}{ Chrysidoidea } & Bethylidae & 2 & 3 & 1 & 1 & 1 & 1 & Parasitoid \\
\hline & Chrysididae & 0 & 0 & 1 & 1 & 0 & 0 & Parasitoid \\
\hline & Drynidae & 0 & 0 & 0 & 0 & 1 & 1 & Parasitoid \\
\hline & Embolemidae & 1 & 1 & 0 & 0 & 0 & 0 & Parasitoid \\
\hline \multirow[t]{5}{*}{ Vespoidea } & Tiphiidae & 0 & 0 & 1 & 2 & 1 & 1 & Parasitoid \\
\hline & Pompilidae & 6 & 32 & 7 & 29 & 10 & 24 & Pollinator \\
\hline & Scoliidae & 2 & 4 & 2 & 4 & 0 & 0 & Parasitoid \\
\hline & Vespidae & 7 & 31 & 9 & 47 & 5 & 15 & Predator \\
\hline & Formicidae & 29 & 728 & 33 & 587 & 29 & 500 & Predator \\
\hline \multirow[t]{6}{*}{ Apoidea } & Ampulicidae & 1 & 1 & 0 & 0 & 0 & 0 & Predator \\
\hline & Sphecidae & 5 & 9 & 5 & 11 & 5 & 22 & Predator \\
\hline & Colletidae & 2 & 16 & 2 & 4 & 1 & 2 & Pollinator \\
\hline & Halictidae & 2 & 5 & 3 & 15 & 5 & 54 & Pollinator \\
\hline & Megachilidae & 1 & 1 & 0 & 0 & 0 & 0 & Pollinator \\
\hline & Apidae & 0 & 0 & 1 & 15 & 1 & 5 & Pollinator \\
\hline \multirow[t]{2}{*}{ Ichneumonoidea } & Braconidae & 22 & 87 & 29 & 158 & 17 & 55 & Parasitoid \\
\hline & Ichneumonidae & 25 & 36 & 31 & 68 & 25 & 44 & Parasitoid \\
\hline Evanioidea & Evaniidae & 9 & 70 & 12 & 56 & 7 & 30 & Parasitoid \\
\hline \multirow{2}{*}{ Cynipoidea } & Figitidae & 1 & 3 & 0 & 0 & 0 & 0 & Parasitoid \\
\hline & Eucoilidae & 6 & 24 & 8 & 48 & 4 & 7 & Parasitoid \\
\hline Proctotrupoidea & Diapriidae & 26 & 124 & 28 & 132 & 17 & 63 & Parasitoid \\
\hline \multirow[t]{2}{*}{ Platygastroidea } & Platygastridae & 10 & 22 & 12 & 33 & 6 & 5 & Parasitoid \\
\hline & Scelionidae & 42 & 249 & 52 & 417 & 33 & 145 & Parasitoid \\
\hline \multirow[t]{2}{*}{ Ceraphronoidea } & Megaspilidae & 0 & 0 & 0 & 0 & 1 & 1 & Parasitoid \\
\hline & Ceraphronidae & 4 & 6 & 5 & 29 & 7 & 24 & Parasitoid \\
\hline Mymarommatoidea & Mymarommatidae & 2 & 4 & 5 & 15 & 3 & 5 & Parasitoid \\
\hline \multirow{13}{*}{ Chalcidoidea } & Chalcididae & 6 & 9 & 8 & 11 & 11 & 19 & Parasitoid \\
\hline & Eurytomidae & 6 & 20 & 11 & 24 & 3 & 4 & Parasitoid \\
\hline & Pteromalidae & 5 & 15 & 5 & 32 & 3 & 8 & Parasitoid \\
\hline & Torymidae & 0 & 0 & 2 & 7 & 1 & 1 & Parasitoid \\
\hline & Ormyridae & 1 & 2 & 1 & 11 & 1 & 1 & Parasitoid \\
\hline & Eupelmidae & 5 & 11 & 9 & 10 & 1 & 1 & Parasitoid \\
\hline & Encyrtidae & 5 & 15 & 6 & 12 & 6 & 10 & Parasitoid \\
\hline & Aphelinidae & 2 & 2 & 2 & 9 & 3 & 5 & Parasitoid \\
\hline & Tetracampidae & 1 & 2 & 2 & 16 & 0 & 0 & Parasitoid \\
\hline & Eulophidae & 14 & 23 & 31 & 151 & 12 & 21 & Parasitoid \\
\hline & Elasmidae & 2 & 16 & 2 & 10 & 1 & 2 & Parasitoid \\
\hline & Trichogrammatidae & 4 & 5 & 9 & 41 & 2 & 5 & Parasitoid \\
\hline & Mymaridae & 2 & 6 & 6 & 26 & 3 & 4 & Parasitoid \\
\hline Total & & 185 & 1,584 & 207 & 2,032 & 171 & 1,085 & \\
\hline
\end{tabular}

Table 5. Total of morphospecies, abundance, evenness index and diversity index of Hymenoptera at three different stages of rice cultivation in Indragiri Hilir District, South Sumatra, Indonesia

\begin{tabular}{|c|c|c|c|c|c|c|c|c|c|}
\hline \multirow{2}{*}{ Indicator/phase } & \multicolumn{3}{|c|}{ Before planting } & \multicolumn{3}{|c|}{ Vegetative phase } & \multicolumn{3}{|c|}{ Generative phase } \\
\hline & Parasitoid & Pollinator & Predator & Parasitoid & Pollinator & Predator & Parasitoid & Pollinator & Predator \\
\hline Morphospecies & 120 & 14 & 44 & 92 & 11 & 28 & 133 & 17 & 46 \\
\hline Individual abundance & 1,105 & 64 & 944 & 578 & 31 & 317 & 865 & 107 & 690 \\
\hline Evenness index (E) & 0.85 & 0.89 & 0.66 & 0.83 & 0.82 & 0.74 & 0.86 & 0.86 & 0.82 \\
\hline Diversity index (H') & 4.05 & 2.35 & 2.5 & 3.77 & 1.98 & 2.45 & 4.20 & 2.43 & 3.14 \\
\hline
\end{tabular}


Table 3. Total of morphospecies, abundance, evenness index and Hymenoptera diversity index in Indragiri Hilir District, South Sumatra, Indonesia

\begin{tabular}{llll}
\hline Indicator & Parasitoid & Pollinator & Predator \\
\hline Total of morphospecies & 222 & 25 & 72 \\
Individual abundance & 2,548 & 202 & 1,951 \\
Evenness index (E) & 0.93 & 0.95 & 0.88 \\
Diversity index (H') & 5.05 & 3.06 & 3.76 \\
\hline
\end{tabular}

Table 4. Similarity index of species of Hymenoptera among the three studied areas in Indragiri Hilir District, South Sumatra, Indonesia

\begin{tabular}{lcc}
\hline Sub-district/parasitoid & Keritang & Reteh \\
\hline Batang Tuaka & 0.44 & 0.37 \\
Keritang & - & 0.39 \\
& & \\
Sub-district/pollinator & Keritang & Reteh \\
Batang Tuaka & 0.26 & 0.33 \\
Keritang & - & 0.30 \\
& & \\
Sub-district/predator & Keritang & Reteh \\
Batang Tuaka & 0.39 & 0.35 \\
Keritang & - & 0.43 \\
\hline
\end{tabular}

The results of this study revealed that tidal swamp rice at three study areas in Indragiri Hilir District had a high Hymenoptera parasitoid and predator diversity index, while Hymenoptera pollinators were had moderate diversity index (Table 3). The high diversity of parasitoid and predator of Hymenoptera is a potential that must be maintained in order to suppress pest attacks on cultivated plants.

Similarity levels of morphospecies of Hymenoptera parasitoids, pollinators, and predators on tidal swamp rice in the three studied areas were classified as low. With this criterion, species present in one sub-district were almost not the same as the species in the other sub-districts. It means that the composition of the constituent ecosystem is relatively unequal. Then, this also revealed that not all Hymenoptera parasitoids, pollinators, and predators morphospecies could be found in three sub-districts (Table 4).

The diversity of Hymenoptera in this study showed a high diversity at the time before planting, then decrease in the vegetative phase, and increase in the generative phase (Table 5). This was likely caused by the many types of weeds that existed before planting stage. Our finding is in line with the result of previous study that complex agricultural landscapes can increase parasitoid diversity (Yaherwandi et al. 2008). The evenness values of species were high, meaning that there were no species that dominated the ecosystems (Table 6).

The results showed that the Hymenoptera at the studied areas consisted of parasitoids, pollinators, and predators. Each sub-district had the three groups but there were different values across sub-districts (Table 6). There was decreasing number of individuals of Hymenoptera insects due to reduced types of vegetation plants. Agricultural areas at the time before planting consisted of many types of weed vegetation then became dominated by rice in the vegetative period. This made the availability of food of various kinds of insects was reduced so that the number of morphospecies and the number of individual insects of Hymenoptera was also reduced. Species richness of predators and parasitoids in local cropping systems tended to be higher than in conventional systems for all stages of planting and types of swamplands (tidal swamp and back swamp) (Rosa and Mariana 2012).

We found that the morphospecies diversity and individuals in the group of parasitoid were higher than the other groups. This is because the order of Hymenoptera is dominated with species classified as parasitoid and parasitoid insects are abundant in terrestrial ecosystems (LaSalle 1993). Hymenoptera parasitoids have been widely used as biological agents. For example, several species of the Braconidae family are used as parasitoids to control various pests on crops (Lv et al. 2011; Tomanović et al. 2013), some species of the Ichneumonidae family as parasitoids in larvae and pupae of Lepidoptera pests in agroecosystems (Mason 2013), several species of the Scionionae family as parasitoids in rice and oil palm plantations (Pebrianti et al. 2016) and several species of the Trichogrammatidae family as parasitoids to control pests in agroecosystems (Hidrayani et al. 2013; Sangha et al. 2018). The finding of our study suggests that the Hymenoptera parasitoid has the potential to become a biological agent in Indragiri Hilir District.

Table 6. Total of morphospecies, abundance, evenness index and diversity index of Hymenoptera at three study areas in Indragiri Indragiri Hilir District, South Sumatra, Indonesia

\begin{tabular}{lccccccccc}
\hline \multirow{2}{*}{ Indicator/Sub-district } & \multicolumn{3}{c}{ Batang Tuaka } & \multicolumn{3}{c}{ Keritang } & \multicolumn{3}{c}{ Reteh } \\
\cline { 2 - 9 } & Parasitoid & Pollinator & Predator & Parasitoid & Pollinator & Predator & Parasitoid & Pollinator & Predator \\
\hline Morphospecies & 133 & 11 & 42 & 147 & 13 & 47 & 115 & 17 & 39 \\
Individual abundance & 761 & 54 & 769 & 1,324 & 63 & 645 & 463 & 85 & 537 \\
Evenness index (E) & 0.97 & 0.96 & 0.92 & 0.96 & 0.96 & 0.92 & 0.97 & 0.93 & 0.93 \\
Diversity index (H') & 4.74 & 2.31 & 3.42 & 4.78 & 2.47 & 3.53 & 4.60 & 2.63 & 3.40 \\
\hline
\end{tabular}


Various research showed that treatment in the form of agrochemical inputs (especially pesticides and fertilizers) has caused unwanted environmental and social impacts (Barriere et al. 2015), while the organic rice farming system can increase species richness, species evenness and heterogeneity of insect (Ovawanda et al. 2016). In the context of the Hymenoptera parasitoid, its diversity was influenced by the landscape structure (Yaherwandi 2009). In summary, our study found 4,701 individuals consisting of 39 families and 319 morphospecies of Hymenoptera on tidal swamp rice in Indragiri Hilir District. Tidal swamp rice in Indragiri Hilir District had a high species diversity of Hymenoptera parasitoids and Hymenoptera predators, but a moderate species diversity of Hymenoptera pollinators. Species diversity and evenness of Hymenoptera parasitoids and predators were higher in Keritang than in Batang Tuaka and Reteh. The families of Formicidae, Braconidae, Ichneumonidae, and Scelionidae had the highest number of species, while Formicidae, Scelionidae, Diapriidae, and Braconidae had the highest number of individuals. Based on these findings, the abundance and diversity of Hymenoptera insects in Indragiri Hilir District have the potentials to be developed as biological agents to control pests on tidal swamp rice in Indragiri Hilir District.

\section{ACKNOWLEDGEMENTS}

The authors are grateful to the Indonesian Ministry of Research Technology and Higher Education, and LPDP for giving the scholarship and financial support for this research.

\section{DAFTAR PUSTAKA}

Aguiar AP, Deans AR, Engel MS, et al. 2013. Order Hymenoptera. Zootaxa, 3703 (1): 51-62. DOI: 10.11646/zootaxa.3703.1.12

Barriere V, Lecompte F, Lescourret F. 2015. Efficacy of pest and pathogen control, yield and quality of winter lettuce crops managed with reduced pesticide applications. European Journal of Agronomy 71: 34-43. DOI: 10.1016/j.eja.2015.07.003

Darnaedi D, Noerdjito WA. 2007. Understanding Indonesian Natural Diversity: Insect-Collecting Methods Taught to Parataxonomists During DIWPA-IBOY Training Courses. Proceedings of International Symposium "The Origin and Evolution of Natural Diversity," Sapporo, Japan.

Goulet H, Huber JT. 1993. Hymenoptera of the World: An Identification Guide to Families. Canada Communication Group, Canada.

Hariyanti IA. 2015. Keanekaragaman dan Kelimpahan Serangga Parasitoid di Lahan Tebu Desa Pakisjajar Kecamatan Pakis Kabupaten Malang. Universitas Negeri Malang, Malang. [Indonesian]

Herlina N, Rizali A, Moerfiah, Sahari B, Buchori D. 2011. Pengaruh habitat sekitar lahan persawahan dan umur tanaman padi terhadap keanekaragaman Hymenoptera parasitika. J Entomol Indon 8 (1): 17 26. DOI: $10.5994 /$ jei.8.1.17-26. [Indonesian]

Herlinda S. 2007. Struktur Komunitas dan Potensi Kumbang Carabidae dan Laba-Laba Penghuni Ekosistem Sawah Dataran Tinggi Sumatera
Selatan. Seminar dan Konferensi Nasional Konservasi Serangga, Bogor, 27-30 Januari 2007. [Indonesian]

Hidrayani, Rusli R, Lubis YS. 2013. Keanekaragaman Spesies Parasitoid Telur Hama Lepidoptera dan Parasitisasinya pada Beberapa Tanaman di Kabupaten Solok, Sumatera Barat. Jurnal Natur Indon 15 (1): 9-14. [Indonesian]

Ikhsan Z, Hidrayani, Yaherwandi, Hamid H. 2018. Inventarisasi Serangga Pertanaman Padi Pasang Surut Pada Saat Sebelum Tanam di Kabupaten Indragiri Hilir, Riau. Selodang Mayang 4 (1): 51-59. [Indonesian]

Kalshoven L. 1981. The Pest of Crops in Indonesia. Ichtiar Baru-Van Hoeve, Jakarta.

Krebs CJ. 2000. Ecological Methodology. 2nd ed. Benjamin Cummings, New York.

LaSalle J. 1993. Parasitic Hymenoptera, biological control and biodiversity. In: Hymenoptera and Biodiversity. CAB International, Wallingford, UK.

Lv J, Wilson LT, Beuzelin JM, White WH, Reagan TE. 2011. Impact of Cotesia flavipes (Hymenoptera: Braconidae) as an augmentative biocontrol agent for the sugarcane borer (Lepidoptera: Crambidae) on $\begin{array}{lllll}\text { rice. Biol Conserv } 56 & \text { (1): 159-169. DOI: }\end{array}$ 10.1016/j.biocontrol.2010.10.005

Mason PG. 2013. Biological control in Ontario 1952 - 2012 : a summary of publications in the "Journal of the Entomological Society of Ontario.” J Entomol Soc Ontario 144 (1): 27-111.

Ovawanda EA, Witjaksono, Trisyono YA. 2016. Insect biodiversity in organic and non-organic rice ecosystems in the district of Bantul. Jurnal Perlindungan Tanaman Indonesia 20 (1): 15-21.

Pebrianti HD, Maryana N, Winasa IW. 2016. Keanekaragaman parasitoid dan artropoda predator pada pertanaman kelapa sawit dan padi sawah di Cindali, Kabupaten Bogor. Jurnal Hama dan Penyakit Tumbuhan Tropika 16 (2): 138-146. [Indonesian]

Rosa HO, Mariana. 2012. Predators and parasitoids on ricefield of back swamp and tidal swamplands in South Kalimantan. Intl J Sci Res 3 (10): 759-763.

Sangha KS, Shera PS, Sharma S, Kaur R. 2018. On-farm impact of egg parasitoid, Trichogramma spp. against lepidopteran pests in organic basmati rice. J Biol Contr 32 (2): 116-120. DOI: $10.18311 / \mathrm{jbc} / 2018 / 16272$

Siregar EH, Atmowidi T, Kahono S. 2016. Diversity and abundance of insect pollinators in different agricultural lands in Jambi, Sumatera. Hayati J Biosci 23 (1): 13-17. DOI: 10.1016/j.hjb.2015.11.002

Thamrin M. 2011. Keberadaan musuh alami pada areal padi dan gulma teki di lahan rawa pasang surut. Prosiding Seminar Nasional: Hidup Sejahtera Bersama Serangga. Perhimpunan Entomologi Indonesia Cabang Bandung, Bandung. [Indonesian]

Tomanović Ž, Starý P, Kavallieratos NG, Gagić V, Plećas M, Janković M, et al. 2013. Aphid parasitoids (Hymenoptera: Braconidae: Aphidiinae) in wetland habitats in western Palaearctic: key and associated aphid parasitoid guilds. Intl J Entomol 48 (1): 189-198. DOI: $10.1080 / 00379271.2012 .10697763$

Triplehorn CA, Johnson NF. 2004. Borror and DeLong's Introduction to the Study of Insect. 7th ed. Cengage Learning, Stamford, USA.

Untung K. 1996. Pengantar Pengelolaan Hama Terpadu. UGM Press, Yogyakarta. [Indonesian]

Yaherwandi. 2009. Struktur komunitas Hymenoptera parasitoid pada berbagai lanskap pertanian di Sumatra Barat. J Entomol Indon 6 (1): 1-14. [Indonesian]

Yaherwandi. 2012. Community structure of parasitoids Hymenoptera associated with Brassicaceae and non-crop vegetation. Nusantara Biosci 4 (1): 22-26. DOI: 10.13057/nusbiosci/n040105

Yaherwandi, Manuwoto S, Buchori D, Hidayat P, Prasetyo LB. 2008. Struktur komunitas hymenoptera parasitoid pada tumbuhan liar di sekitar pertanaman padi di Daerah Aliran Sungai (DAS) Cianjur, Jawa Barat. Jurnal Hama dan Penyakit Tumbuhan Tropika 8 (2): 90101. [Indonesian] 